\title{
Household Behavior and Demand for Better Solid Waste Management Services: A Case of Bahir Dar City, Amhara National Regional Stat, Ethiopia
}

\section{Kassahun Tassie Wegedie}

Department of Agricultural Economics, College of Agriculture and Environmental Science, Bahir Dar University, Ethiopia

"Corresponding author: Tassie Wegedie K, Department of Agricultural Economics, College of Agriculture and Environmental Science, Bahir Dar University, Ethiopia, Tel: 251975095076/251918302362; E-mail: tasiekassahun@gmail.com

Received: January 01, 2018; Accepted: January 08, 2018; Published: January 15, 2018

Copyright: (c) 2018 Tassie Wegedie K. This is an open-access article distributed under the terms of the Creative Commons Attribution License, which permits unrestricted use, distribution, and reproduction in any medium, provided the original author and source are credited.

\begin{abstract}
The research examines the households' determinate factors for solid waste generation and WTP for better SWM system of households in Bahir Dar city. The data were subjected to both descriptive and econometric technique of analysis. Stratified and simple random sampling methods were used to select 196 households for primary data collection. Multiple linear regression analysis was used to determine households' solid waste generation determinant factors and logit model for their WTP ability analysis. The result shows that mean weight waste generation by sample households was $0.22 \mathrm{~kg}$ per capita per day. Only $31 \%$ of sample households have separate bins and the remaining households do not have separate bins for storage of different types of waste separately for simple waste management purpose. Results multiple linear regression showed that household size and household total income were determinate factors of households solid waste generation in the study area. Most households $86.2 \%$ are willing to cooperate with the government in financing solid waste management in order to improve this condition. The average monthly willingness to pay is Birr 11.30 Birr per month per household and it shows difference across zones. The willingness to pay is higher in the inner and lower in the outer zone. From logit model analysis, the main determinate factor of households "Willingness to Pay" is income. The result of this study suggests there is a good chance of success if solid waste management service charges are introduced, and these charges should take into consideration both households ability and willingness to pay.
\end{abstract}

Keywords: WTP; Solid waste management; Multiple linear regression

\section{Introduction}

Nowadays, the world's environment gets polluted and it's comfortablity for life becoming decline. The most vital engines for environmental pollution are rapid urbanization, fast expansion of urban agricultural and industrial activities, which stimulated by population growth [1]. Economic growth in less developed countries has led to the massive movements of people from less urban areas to urban areas for searching better life [2]. Because of this, the number of persons added to the urban population in unindustrialized countries indicates the challenges faced by governments, urban planners, nongovernmental service providers and urban residents [3]. Due to this, urbanization and high rate of population growth are solely responsible for high increasing rate of solid waste management (SWM) service supply [4]. Even though developed countries generate greater quantity of solid waste than developing countries [5]. The problem in less developed nations is further complicated because of increasing greatly the volume and composition of waste being generated and the demand for waste retrieval service in municipal areas by rapid growth in population and urbanization [6]. This implies that the problem of SWM in the developing world is more acute than developed countries, because as long as humans have been living in settled communities, waste generation has been an obvious and serious issue in all nations [7].
In developing countries, improper handling, collection, transportation and disposal of solid wastes in landfill contribute to high level of mortality and morbidity even if produce less per capita solid waste [8]. Because of cities and municipalities cannot cope up with the accelerated rate of waste production and composition in terms of technology, institutional arrangement and cost effectiveness of SWM $[9,10]$. Due to these, improper municipal solid waste disposal and management causes all types of pollution i.e., air, soil and water pollution [11]. This indicated that human health and ecosystem service is threatened by inadequate SWM system [6]. Even though the overall goal of urban solid waste management is to collect, treat and dispose of solid waste generated by all urban dwellers, $30-60 \%$ of all the urban solid wastes are uncollected, and not greater than $50 \%$ of the inhabitants is served by the municipality waste collectors [12]. As a consequence, inefficient municipal solid waste management system increase disease transmission, contaminate ground and surface water, create greenhouse gas emissions, damage ecosystem services, discourages tourism and other business activities $[11,13]$.

In line with this, solid waste management is becoming a major public health and environmental concern in urban areas of Ethiopia though only $2 \%$ of the population received solid waste collection services [14]. Consequently, Bahir Dar city is one of the highly expanding and rapidly growing cities in Ethiopia [15,16] with the current annual population growth rate of $6.6 \%$ continues, the city population will double in 11 years increase pressure for the management of municipal solid waste in order to outbreak disease $[17,18]$. Thus the need for adequate solid waste management is unquestionable [18]. According to UNEP [16], one of the challenges 
Citation: Tassie Wegedie K (2018) Household Behavior and Demand for Better Solid Waste Management Services: A Case of Bahir Dar City, Amhara National Regional Stat, Ethiopia. Adv Recycling Waste Manag 3: 152. doi:10.4172/2475-7675.1000152

Page 2 of 14

that the Ethiopian cities such as Bahir Dar faces are the problem of sanitation in general and municipal solid waste management in particular. A total of 98.8 tons per day solid waste was generated from Bahir Dar city. But the city municipality collects and disposes only $58 \%$ of the total municipal solid waste generated in the city $[16,19]$. This implies that small size of the urban dwellers are served and large quantity of solid waste left uncollected and disposes in open space. From this, we can conclude that the problem of SWM cannot be solved only by mere effort of municipal government (Table 1).

\begin{tabular}{|l|l|l|l|l|}
\hline City & Region & Population & $\begin{array}{l}\text { Municipal solid } \\
\text { waste generation }\end{array}$ & $\begin{array}{l}\text { Municipal } \\
\text { solid waste } \\
\text { collection }\end{array}$ \\
\hline $\begin{array}{l}\text { Addis } \\
\text { Ababa }\end{array}$ & $\begin{array}{l}\text { Addis } \\
\text { Ababa }\end{array}$ & $2,979,100$ & 1,132 tons/day & $70 \%$ collected \\
\hline Mekelle & Tigray & 261,200 & 78 tons/day & $82 \%$ collected \\
\hline Dire Dawa & Dire Dawa & 256,800 & 77 tons/day & $48 \%$ collected \\
\hline Jimma & Oromia & 120,960 & 87 tons/day & $30 \%$ collected \\
\hline Adama & Oromia & 260,600 & 59 tons/day & $48 \%$ collected \\
\hline Bahir Dar & Amhara & 170,300 & 98.8 tons/day & $58 \%$ collected \\
\hline Awasa & SNNPR & 200,400 & 46 tons/day & $44 \%$ collected \\
\hline Harer & Harari & 108,200 & 32 tons/day & $45 \%$ collected \\
\hline Source: (Getahun [21], CSA [22], Fikreyesus [20]. & \\
\hline
\end{tabular}

Table 1: Ethiopian municipalities and waste generation, 2010.

Only few studies in the area of solid waste management are done in Bahir Dar city. Some of these studies include: "liquid waste management" [22,23], "Financial sustainability in municipal solid waste management cooperatives" [17] "plastic bag waste generation rate" [24]; "sustainability of solid waste collection and transport services by micro and small enterprises" [25]; "solid waste characterization and quantification for the development of an integrated solid waste management" [26,27], and "household demand for improved solid waste management services" [28]. Even with all these researches and studies, SWM problem in Bahir Dar city has been increasing over the years. Presently, the duty of municipal SWM services comes under the responsibility of the city municipality. The SWM services supply is provided almost costless using funds available from different sources including government taxes and then budgeted for the municipality. From the total budget of the city municipality, $35-40 \%$ goes for solid waste management activities [29]. Therefore such studies do not guarantee to discuss households' behavior regarding solid waste generation and their willingness to pay (WTP) for better solid waste management services in different zones within the city.

\section{Objectives}

The general objective of this study was to estimate households' households' determinate factors for solid waste generation and their WTP for improved solid waste management services in Bahir Dar city and the following specific objectives:

- To assess the current solid waste management systems in operation in Bahir Dar city;
- To identify determinate factors of households' willingness, pay for improved solid waste management services and solid waste generation;

- To elicit and determine households' WTP for improved solid waste management services supply.

\section{Methodology}

\section{Study area description}

Bahir Dar city is found in the north western part of Ethiopia as shown on the Figure 1, and is faster growing city in Ethiopia [30]. It has a total population of 96,140 in 1994 and 230,344 in 2007 [21], and estimated 297,749 in 2014 [26].

Currently the city is serving as a regional capital city of Amhara National Regional State (ANRS) in Ethiopia. It has become one of the major tourist destinations of the country with a variety of attractions in the nearby Lake Tana (Ethiopia's largest lake and famous for churches and monasteries on the lake's 37 Islands) and Blue Nile river [26]. A global position of the city is between $15^{\circ} 37^{\prime}$ north latitude and $37^{\circ} 25^{\prime}$ east longitude, and enjoys tropical type of climate with $19.6^{\circ} \mathrm{C}$ mean annual temperature and the average elevation of the city is estimated 1801 meters above sea level.

The city has expanded rapidly throughout the $20^{\text {th }}$ century. Today, waste discharges into Lake Tana have become a serious and highly visible problem [26] (Table 2).

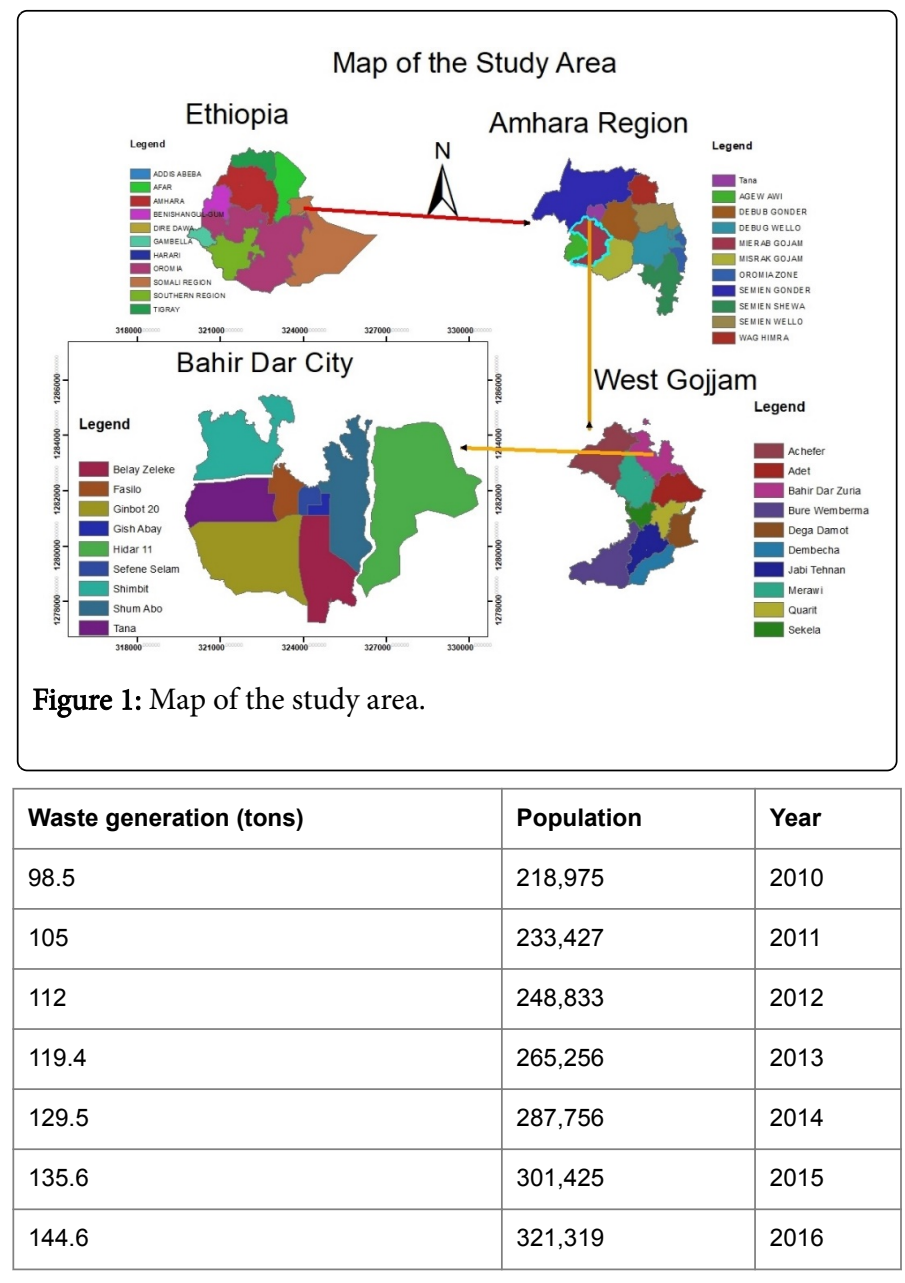




\begin{tabular}{|l|l|l|}
\hline 154 & 342,526 & 2017 \\
\hline 164.4 & 365,333 & 2018 \\
\hline 175.2 & 389,232 & 2019 \\
\hline 186.7 & 414,921 & 2020 \\
\hline 199 & 442,306 & 2021 \\
\hline 212.2 & 471,498 & 2022 \\
\hline Source: (FFE, 2010). & & \\
\hline
\end{tabular}

Table 2: Municipal solid waste generation projection per day of Bahir Dar city.

In Bahir Dar city, population is increasing with high growth rate $(287,756)$ in 2014 and it is 301,425 in 2015 [21]. It is putting immense pressure on municipal services. From different problems of the urbanization and increasing urban population is the increased generation and complexity of waste. This waste is not being sufficiently collect and properly dispose and therefore causes a serious health and ecological risks, particularly in the shantytown areas, where the residents have less capacity to pay for better services and are often ignored by the official agencies. Inadequate urban planning and management are more affected by waste related harms because of unselective discarding and the lack of open space for sanitation services. The final disposal sites are not well designed and managed, and they are open field landfills (no sanitary landfill) and also located close to rural settlements and not at appropriate distance from the center of the city. Due to the above cases dumping sites have negative impacts on soil, ground water and human beings [31]. Therefore, this calls for urgent need for an appropriate need of waste management system by assessing households' solid waste management behavior and their WTP for better service supplied by Bahir Dar city municipality solid waste management department.

The study was conducted primary data sources from households by applying a designed questionnaire by applying face to face interview to reduce non response rate and incompleteness of data. Secondary data were collected from published and unpublished materials, books, websites and reports from different offices in the city. In order to made homogeneity of population of the study area, divided the study area into 52 zones. All zones are not uniform but are heterogeneous in terms of number of peoples in square kilometer, socio-economic actives, access of public and private services and land use planning and management.

\section{Sampling technique}

The choice of sampling technique (probability or non-probability) depends on purpose of the study. So, the objective of this study is to estimate households' willingness to pay for better solid waste management services. For such a quantitative research, probability sampling technique is appropriate as compared to non-probability sampling technique because every sample household has equal chance of being interviewed. Stratified and simple random sampling techniques were used to determine the number of households, in order to collect primary data from these samples to obtain a reasonable and reliable result. The city divided in to 17 administrative Kebelles and after 2007 reforms these Kebelles arranged with a total of 52 zones (smallest legal administrative units). All zones in the city classified into three main groups i.e., inner, middle and Outer based on number of people per kilometer square, public and private organizations, geographical location and socioeconomic activities to make homogenous for primary data collection from sample units. Six zones (11.5\%) from all zones were selected randomly by using lottery method for field data survey. To make the sample zone more representatives, 2 zones from the core, outer and middle zones were selected. Before Zone selection make stratum of zones into three groups that helps to reduce heterogeneous characteristics of households in different zones. Table 3 shows the details about making stratum and proportional sample households' selection.

\section{Data sources}

For the aim of accomplish the objectives of this research, all required data were collected from primary and secondary data sources.

\begin{tabular}{|l|l|l|l|l|l|l|l|}
\hline $\begin{array}{l}\text { Stratum of an } \\
\text { area }\end{array}$ & Sample zones & Total households & $\begin{array}{l}\text { Sample } \\
\text { households }\end{array}$ & $\begin{array}{l}\text { Total Households } \\
\text { (\%) }\end{array}$ & $\begin{array}{l}\text { Area Covered } \\
\text { by sample (Sq. } \\
\text { km.) }\end{array}$ & $\begin{array}{l}\text { Total Population } \\
\text { Population } \\
\text { Density } \\
\text { sq. Km }\end{array}$ \\
\hline inner & A and C & 1904 & 70 & 3.7 & 2.01 & 11424 & 5683 \\
\hline middle & E and B & 1910 & 70 & 3.66 & 2.2 & 9550 & 4341 \\
\hline outer & C and D & 1539 & 56 & 3.6 & 2.15 & 6540 & 3041 \\
\hline Total & 6 zones & 5353 & 196 & 3.66 & 4.36 & 27514 & 6310 \\
\hline
\end{tabular}

Source: Total population data is as per the census of 2007 CSA [21].

Table 3: Sample Households determination across sample zones.

About $3.66 \%$ of sampling units were selected from the total households of the in the selected zones by using random sampling method by applying lottery selection mechanism with help of the sample frame developed before. From all sample zones selected randomly, totally 196 households were selected.

\section{Sample size determination}

In each zone of the city, a list of households was generated from Kebelle administrations to form the sampling frame. A critical component of sample size formulas is the estimation of variance in the primary variables of interest in the study Cochran [32]. Two ways of 
estimating population variances for sample size determinations, (1) use pilot study results and (2) use data from previous studies of the same or a similar population. The sample size was decided by using scientific statistical method developed by Cochran [32]. To determine sample size of households those to participate in the study, a sample size determination formula used which was developed by Cochran [32]. The formula that we used for determining sample size is the following:

$$
n=\frac{N Z^{2} P Q}{d^{2}(N-1)+Z^{2} P Q} 1
$$

Where: $\mathrm{n}=$ sample size; $\mathrm{P}=$ residential Housing unit variable; $\mathrm{Q}=1-\mathrm{P}$; $\mathrm{N}=$ Total numbers of housing units; $\mathrm{Z}=$ standardized normal deviation at the required confidence level that corresponds to $95 \%$ confidence interval equal to 1.96 ; $\mathrm{dd}=$ the level of statistical significance (allowable error which is equal to $0.05=$ our willingness to accept a type I error).

According to data obtained from housing development section of the city (2016), there are about 52,386 legal housing units $(\mathrm{N})$ : from these about $85 \%$ are residential $(\mathrm{P})$ and the rest $15 \%$ are for commercial activities, offices and for others $(\mathrm{Q})$. Therefore based on the above specified formula the required sample size becomes:

$$
n=\frac{52386 \times 1.96^{2} \times 0.85 \times 0.15}{\left(0.05^{2}\right)(52386-1)+\left(1.96^{2}\right)(0.85)(0.15)}=\frac{25658.87}{131.4523} \approx 196
$$

Therefore, minimum sample sizes of 196 households were used for primary data source.

\section{Data collection method}

Sample households profile was gain from the sample frame list of 2017 for the 6 selected zones that government administrative offices used for distribution of basic consumption goods (sugar, palm oil, wheat flour etc). After identifying sample households, two survey instruments were developed to collect data from sample households (i.e., checklist and questionnaire). The main face to face interview data collection was finalized after a pre-test. The major objective of the checklist was to get a general overview of the existing SWM system currently in operation and also helped to identify problems related to solid waste management in the city. The pre-test was made in other zones than the sample zones with 27 sample households before the actual survey. To minimize strategic bias, an introductory statement was included for respondents. The questions were on demographic characteristics of the households, information on waste generation by types, waste disposal practices and door-to-door collection systems. Family income, sources of income, education level, and possession of domestic amenities were also among the questions asked. The questions were filled by visiting the selected households door-to-door from March to April 2017. The households were visited twice to complete the questionnaire. On the first day socio-economic information were collected and households requested to deposit the wastes in different plastic bags. On the next day the wastes were weighted. Three research data collectors (one for two zones) were employed for this work by supervise the researcher myself.

\section{Data analysis methods}

Quantitative and qualitative data gathered through different tools were processed both manually and electronically to complement data from different sources. Quantitative data that were collected from sample households should processed and analyzed using data analysis statistical software STATA version 13. These were done after appropriate coding, edited, and register of collected data, and then enter the data into STATA software. The findings from the analysis were presented by using descriptive statistics (quantitative methods) which includes mean, frequency distribution tables, percentages, and standard deviation methods used in presenting the households profile. The data that were collected from direct physical observation or visualization was analyzed by describing the phenomena using personal judgment and these were also be supported by colored photographs for better qualitative analyzed techniques. Finally conclusion and recommendation was formulated based on findings.

\section{Major findings of the study}

Waste generation in the households: The minimum household size is 1 while the maximum is 9 and the mean household size was found to be 4.18 which is less than the National mean family size of 5 CSA [21]. The Table 4 shows that the mean solid waste generation by the sample households is $0.22 \mathrm{~kg}$ per capita per day $(0.28 \mathrm{~kg}$ in the inner, $0.17 \mathrm{~kg}$ in the outer and $0.20 \mathrm{~kg}$ in the middle zones). There is high average waste generation in inner zones than others. This may be due to more economic activities such as trade and public services of the core zone. In the core zone people have no space even though they generating more wastes per households than other zones.

\begin{tabular}{|l|l|l|l|l|l|l|}
\hline Zone & $\begin{array}{l}\text { Waste generation } \\
(\mathbf{K g} / \text { HH/day) }\end{array}$ & Std. Dev. & Min & Max & $\begin{array}{l}\text { Total waste } \\
\text { (Kg.) }\end{array}$ & $\begin{array}{l}\text { Per capita waste generation /day } \\
\text { (Kg.) }\end{array}$ \\
\hline All zones & 0.91 & 1.27 & 0.35 & 5.15 & 824.14 & 0.22 \\
\hline inner Zone & 0.98 & 1.26 & 0.43 & 5.15 & 255.63 & 0.28 \\
\hline Middle Zone & 0.91 & 1.28 & 0.17 & 5.99 & 320.43 & 0.20 \\
\hline Outer Zone & 0.85 & 1.28 & 0.11 & 3.63 & 248.1 & 0.17 \\
\hline Source: field survey, 2017. & & & & \\
\hline
\end{tabular}

Table 4: Per capita waste generation by the households.

This functional element of SWM constitutes an activity that is carried out both by solid waste generators and solid waste managers of a city. It encompasses an action of storing solid waste in a certain kind of material or equipment as soon as it is generated and safe control of it until it is permanently disposed. As the researcher tried to observe households solid waste separation activities, only solid wastes that are 
sellable to quraleos (persons who practice exchange of recycled wastes in other goods), exchangeable to liwach (exchange recycled solid waste in terms of goods used for different purposes), and to some extent organic wastes are separated. Table 5 shows about the types and proportion of solid waste generated. According to those respondents the dominant types of such wastes includes: Kitchen waste is the major waste in terms of volume and quantity of the selected households. It accounts for nearly $82.2 \%$ of the total waste. Packing waste $15.4 \%$ is next to kitchen waste (69.2\%). Plastic content is $15.4 \%$; whereas paper waste is $4.4 \%$ only. The remaining $5.5 \%$ are other wastes, which include battery, dust, can, electronics wastes etc.

\begin{tabular}{|l|l|l|l|l|l|l|}
\hline Waste types & $\begin{array}{l}\text { Average per } \\
\text { HH per day (Kg.) }\end{array}$ & Std. Dev & Min & Max & $\begin{array}{l}\text { Total waste } \\
(\mathbf{K g})\end{array}$ & $\begin{array}{l}\text { Per Capita } \\
\text { Waste per day(Kg.) }\end{array}$ \\
\hline Kitchen waste & 0.63 & 0.75 & 0.30 & 4.5 & $555.8(82.2)$ & 0.17 \\
\hline Packing waste & 0.14 & 0.23 & 0 & 3.02 & $60.85(9)$ & 0.02 \\
\hline Plastic & 0.14 & 0.22 & 0 & 2.05 & $21.71(3.2)$ & 0.01 \\
\hline Paper & 0.04 & 0.13 & 0 & 2.00 & $16.27(2.4)$ & 0.01 \\
\hline Other Waste & 0.05 & 0.22 & 0 & 3.02 & $21.55(3.2)$ & 0.01 \\
\hline Total Waste & 0.91 & 1.33 & 0.32 & 5.15 & $676.18(100)$ & 0.23 \\
\hline Figure within brackets indicate percentage; (Source: field survey, 2017). & & & & \\
\hline
\end{tabular}

Table 5: Types of waste generated and their proportion across zones.

\section{Existing waste management practices}

Solid waste separation practice: Table 6 presets about the solid waste separation practices of the sample households. Some of solid wastes that are separated by such small number of households are: agricultural waste and food wastes for the purpose of using it as home garden; grass, leaf, waste of sugarcane, waste of cattle's (after dried by sun), wood scrap to use them as fuel; and used papers are reused as toilet paper by family.

\begin{tabular}{|l|l|l|l|l|}
\hline \multirow{2}{*}{ Zones } & \multicolumn{2}{|l}{$\begin{array}{l}\text { Separate } \\
\text { materials }\end{array}$} & storage & $\begin{array}{l}\text { Solid } \\
\text { practice }\end{array}$ \\
\cline { 2 - 5 } & Yes & No & Yes & No \\
\hline All zones & $61(31)$ & $135(69)$ & $45(23)$ & $151(77)$ \\
\hline inner & $13(21)$ & $57(68)$ & $15(33)$ & $55(36)$ \\
\hline Middle & $37(61)$ & $33(24)$ & $22(49)$ & $48(32)$ \\
\hline Outer & $11(18)$ & $45(33)$ & $8(18)$ & $48(32)$ \\
\hline
\end{tabular}

Source: field survey, 2017; Figures within brackets indicate percentage and absolute number indicate the number of households.

Table 6: Separation Practices of the Households.

However, beyond such solid wastes separation of other types in different dwellings of the city is very low. From the total sample households, 135(69\%) households didn't prepare separate storage materials because of different reasons in the study area. Some of these are, lack of spaces, cannot see the importance, cannot afford separated bins, separation consuming time, No ready market for recyclables' materials etc. Among the sample households, only $61(31 \%)$ of the households reported having separate bins for storage of different types of waste. Thus, the majority of the households leave their mixed wastes at one place or in plastic bags. Though about 45(23\%) households separate the reusable and recyclable wastes. Among the sample zones, households having separate storage receptacle is the highest $37(61 \%)$ in the middle zone, lowest $11(18 \%)$ and moderate $13(21 \%)$ in outer and inner zones respectively.

Out of the total sample, 151(77\%) households didn't practice solid waste separation because of different reasons in the study area. Some of these are, lack of spaces, cannot see the importance, cannot afford separated bins, separation consuming time, No ready market for recyclables' materials etc. There was no separation practice, was highest 55(36\%) in the inner zone, and $48(32 \%)$ in middle zone and outer zones. Some of solid wastes that are separated by such small number of households are: agricultural waste and food wastes for the purpose of using it as home garden; grass, leaf, waste of sugarcane, waste of cattle's (after dried by sun), wood scrap to use them as fuel; and used papers are reused as toilet paper by family.

Door-to-Door collection: Table 7 shows households who receives services by the city solid collectors and satisfied or not about current SWM system. Only $112(57 \%)$ households were received door-to-door solid waste collection services and the rest $84(43 \%)$ did not gain. From the total households who receives service, $56(50 \%)$ were from inner zones. The majority of them receive the service by paying the fee $8 \mathrm{~EB}$ with water bill and few are receiving the service not because of the fee but because of the location of their house along the road and center of the city. From those who didn't receive services $42(50 \%)$ households' were from outer zones. This is because of outer zone households in most case did not have water bill and they live with less infrastructure facility like road. Municipal collectors provide the service without receiving any bonus since they are the employees of the municipality. They gain monthly wage from $750-4500$ EB based on their position and number of households provide service. 
Citation: Tassie Wegedie K (2018) Household Behavior and Demand for Better Solid Waste Management Services: A Case of Bahir Dar City, Amhara National Regional Stat, Ethiopia. Adv Recycling Waste Manag 3: 152. doi:10.4172/2475-7675.1000152

Page 6 of 14

\begin{tabular}{|l|l|l|l|l|l|l|l|}
\hline \multirow{2}{*}{ Zones } & \multicolumn{3}{l}{$\begin{array}{l}\text { Total No. of HH with Door to Door } \\
\text { Collection service }\end{array}$} & $\begin{array}{l}\text { Satisfied with the present collection } \\
\text { system }\end{array}$ & \multicolumn{4}{l|}{ Environmentally safe disposal of the collected waste } \\
\cline { 2 - 8 } & Gain & Not gain & Satisfied & Not Satisfied & Yes & No & Don't know \\
\hline All zones & $112(57)$ & $84(43)$ & $38(19.4)$ & $158(80.6)$ & $18(9)$ & $51(26)$ & $127(64.8)$ \\
\hline inner & $56(50)$ & $14(16.7)$ & $22(57.9)$ & $48(30.4)$ & $13(72.2)$ & $17(33.3)$ & $40(31.5)$ \\
\hline Middle & $42(37.5)$ & $28(33.3)$ & $13(34.2)$ & $57(36.1)$ & $4(22.2)$ & $21(41.2)$ & $45(35.4)$ \\
\hline Outer & $14(12.5)$ & $42(50)$ & $3(7.9)$ & $53(33.5)$ & $1(5.6)$ & $13(25.5)$ & $42(33.1)$ \\
\hline Source: field survey, $2017:$ Absolute number indicate the number of households and Figure within bracket indicate percentages. &
\end{tabular}

Table 7: Door-to-door collection and disposal of waste.

As we described earlier, door to door solid waste collection system of the city is insignificant both in spatial coverage and efficiency. The survey result shows from the total sample $43 \%$ households never received solid waste management services provided by the municipality. As a result, the only solid waste disposal option of household is restricted to two choices. The first one is simply burning, burying, or dumping of solid waste in their compounds. While the second option is throwing of solid waste at roadsides, open fields, nearby rivers, bridges and gullies. Even households who received solid waste management services practice illegal wastes disposal because of they didn't get the services up on the plan of the municipality (once a week for residents; per day for star hotels; and per three days for cafe and restaurants). Hence in order to assess the routine method of solid waste disposal practices of households and to know the destination of uncollected solid wastes, the researchers asked sample respondents about their common disposal system. From the total sample, 130(66.3\%) households practice illegal solid waste disposal, and only the rest 63(32.1\%) households wait until solid waste collectors come. This indicates even households who receive service from the municipality disposed wastes illegally. It has been observed and concluded that open disposal of solid waste is the most usual activity have been done by residents of Bahir Dar city and these makes high probability of environmental pollution, breeding grounds of insects, pests and infectious diseases and also produce toxic gases, which spread odor around the dumping places and block drainage channels.

The cleanness of environment of an area depends on the regularity in the collection of waste by the city waste collectors. As expected the majority of respondents are not satisfied by the current SWM system in Bahir Dar city. Table 8 shows that most households 158(80.6\%) were not satisfied with the present door-to-door collection, transportation and disposal system. Only $19.4 \%$ were satisfied with what the government is doing in make a clan city for residents as well as tourists and also shows that households who gates solid waste management services are not satisfied. The percentage of unsatisfied households is higher in the middle zone relative to the core and outer zones. This may related with spatial coverage of service provision of the municipality who gives more focus for core and in some extent middle zones of the city because of its economic activities related to transport, trade and other public services. The data analysis also tries to assess households' perception about SWM system. From the total sample, only $9 \%$ households sense that the current SWM system is environmentally safe, $23.5 \%$ respond not positive for environment and the remaining majority households (64.8\%) could not explain the effect of current waste management system on environment.

Waste collectors and collection frequency: As we explained Bahir Dar city municipality solid waste management department planned to provide door-to-door solid waste collection services for resident once per week in regular way by private small scale enterprises. But the reality was not as shown below. Table 8 shows the detail regarding the waste collection frequency and collectors in the study city. Among the zones, municipal collectors are collecting wastes in the inner area whereas NGOs no any type roles in all zones and a private firm, street sweeping and wage workers working in all zones even if their distribution is not fair. This is because of number of households in the area and economic activities that may generate high volume of waste (example market centers, transport areas etc.).

\begin{tabular}{|l|l|l|l|l|l|l|l|l|}
\hline \multirow{2}{*}{ Zones } & \multicolumn{2}{|l|}{ Collectors } & \multicolumn{3}{l|}{ Collection Frequency } \\
\cline { 2 - 9 } & $\begin{array}{l}\text { Wage } \\
\text { Workers }\end{array}$ & $\begin{array}{l}\text { Street } \\
\text { sweeping }\end{array}$ & Pvt & weekly & every 15 days & Every 21 days & Per month & Not at all \\
\hline All zone & $74(100)$ & $131(100)$ & $216(100)$ & $53(47.3)$ & $18(16)$ & $29(25.9)$ & $12(10.7)$ & $84(43)$ \\
\hline inner & $34(46)$ & $60(45.8)$ & $97(45)$ & $35(66)$ & $6(10.7)$ & $8(14.3)$ & $0(0)$ & $21(25)$ \\
\hline Middle & $22(29.7)$ & $45(34.4)$ & $75(35)$ & $11(26.2)$ & $10(23.8)$ & $17(40.5)$ & $4(9.5)$ & $28(33)$ \\
\hline Outer & $18(24.3)$ & $26(19.8)$ & $44(20)$ & $7(13)$ & $2(14.3)$ & $4(28.6)$ & $8(57.1)$ & $35(42)$ \\
\hline
\end{tabular}


Table 8: Waste collectors and Collection frequency.

Ethiopia has Environmental policy and solid waste management proclamation, (No. 513/2007). Thus addresses diverse environmental matters including SWM. The bases for the Environmental Policy of Ethiopia [33] are articles 92.1 and 92.2 of the constitution of a nation. These articles state the right of people who lives in Ethiopia regardless of urban and rural: Article 92.1"government shall endeavor to ensure that all Ethiopians live in a clean and healthy environment" and Article 92.2 "both an authority and the people shall have the responsibility to keep the environment from any destructive activities. However, ANRS has not yet design any law or act on environmental issues. It is rather using the federal laws but facing difficulty on enforcement and monitoring at regional level [26]. From the table above, the result shows only 53(47.3\%) households received solid waste management services weekly. While 18(16\%) households, 29(25.9\%) households, $12(10.7 \%)$ households received solid waste management services within 15 days, 21 days and once in a month, respectively, and 84(43\%) residents never received solid waste collection, transportation and final disposal in to landfill services until this interview was made. These indicate a huge faillarity of environment protection from pollution. In general solid waste management services provided by the municipality waste collectors is not fair even in waste management frequency.

Households' solid waste disposal practices: Table 9 shows households solid waste management methods adopted when there is door-to-door collection service. As we described earlier, house to house solid waste collection of the city is insignificant both in spatial coverage and efficiency. As a result, the only solid waste disposal option of household is restricted to two choices. The first one is simply burning, burying, or dumping of solid waste in their compounds. While the second option is throwing of solid waste at roadsides, open fields, nearby rivers, bridges and gullies. Even households who received SWM services practice illegal wastes disposal because of they didn't get the services up on the plan of the municipality (once a week for residents; per day for higher level star hotels; and per three days for cafe and restaurants).

\begin{tabular}{|c|c|c|c|c|}
\hline Management Practices & Total Number of HH & Core & Middle & Outer \\
\hline Total Number of $\mathrm{HH}$ & 196 & 70 & 70 & 56 \\
\hline Throwing in the Container & $8(4)$ & $6(8)$ & $4(5)$ & $2(3)$ \\
\hline Throwing in the road & $31(16)$ & $35(50)$ & $10(14)$ & $6(10)$ \\
\hline Throwing in open field & $26(13)$ & $11(16)$ & $10(15)$ & $6(11)$ \\
\hline Burying in own land & $43(22)$ & $6(8)$ & $17(24)$ & $13(24)$ \\
\hline Prepare the compost from waste & $22(11)$ & $4(6)$ & $10(14)$ & $5(9)$ \\
\hline Cattle feeding & $4(2)$ & $0(0)$ & $2(3)$ & $1(1)$ \\
\hline Burn & $48(25)$ & $6(8)$ & $16(23)$ & $18(32)$ \\
\hline Throw in the river & $14(7)$ & $2(4)$ & $1(2)$ & $6(10)$ \\
\hline Total $\mathrm{N}^{\circ}$ of $\mathrm{HH}$ with different practices & 196(100) & $70(100)$ & $70(100)$ & $56(100)$ \\
\hline
\end{tabular}

Table 9: Method of waste disposal adopted by the household.

Hence in order to assess the common method of solid waste discarding methods of households and to know the destination of uncollected solid wastes, the researchers asked sample respondents about their common disposal system. From the total sample, 131(66.8\%) households practice illegal solid waste disposal, and only the rest 35(33.2\%) households wait until solid waste collectors come. The survey result shows that illegal waste disposal methods look like the following: From the Table 10, it is clear that $48(25 \%)$ of households practiced burning of the waste and $22(11 \%)$ of households practice burry inside the compound and simply dispose the waste in the compound. This activity is a peril for high risk on the local environment and human health. These result shows even households who have been get solid waste management services from municipality practice illegal solid waste disposal because of service provision period with in long period interval and irregularity.

Table 10 also shows the difference across sample zone residents' solid waste management methods. Number of people who throwing waste into the road is higher in the inner zone than middle and outer zones. This may related with absence of open spaces and rivers for waste disposal options. When we seen throwing waste in to the river outer zones is higher than other zones. It has been observed and concluded that still open dumping of waste is the most prevailing activity practiced by residents of Bahir Dar city and these makes high probability of environmental pollution, breeding grounds of insects, pests and infectious diseases and also produce toxic gases, which 
spread odor around the dumping places and block drainage channels. Therefore, the participation of the whole community in the municipal SWM of the city is very essential and highly expected to bring changes on the existing low status of SWM service supply.

\section{Econometric model specification}

Given the type of data two econometric models (multiple linear and binary logit) were used to make deferential data analysis for this study

Specification of multiple linear regression model and data analysis: Households' quantity of solid waste generation will depend upon different important determinant factors. In this study HH's quantity of waste generation is take as the explained variable, and it is taken as continuous variable. Normally household quantity of waste generation is a function of consumption and consumption also is a function of different determinant factors that may affect positively or negatively. The relationship between waste and consumption activities may be expressed as Richardson [34]:

\section{$\mathrm{W}=\beta \mathrm{C} \quad(2)$}

Where, W=vector quantity and composition of solid waste; $\beta=$ Vector of coefficients relating the types and quantities of solid waste to each consumption activity; $\mathrm{C}=\mathrm{is}$ a vector of consumption activities identified by consumer household.

This study was designed to obtain data on determinant factors that influence households' solid waste generation in Bahir Dar city. Like other environmental goods quantity of waste generated expected to be affected by various factors. The main contributing factor of households total consumption activities are assumed to be household monthly income (TOTI), size of the household (TOTPOP), educational status of the household (GRAD); and extra land area in the house compound (EXTLA), and SER=solid waste management services availability in the study city. Since the dependent variable quantity of waste generated per household per day is continuous, the appropriate Econometric model is multiple linear regression model. Since using other models in this circumstance will result inappropriate estimates. The model is specified as:

\section{TOTW $=\beta_{0}+\beta_{1}$ TOTI $+\beta_{2}$ TOTPOP $+\beta_{3}$ GRAD $+\beta_{4}$ EXTL $+\beta_{5}$ SERV $+\beta_{6} \mathrm{AGEHH}+\mathrm{e}$}

Here level of output produced from consumers (production unit) is quantity of waste.

\section{Definition of explanatory variables and hypothesized as follows:}

i. TOTI-This variable refers total income of a household and other members from all sources of income. Income is a main determinant of demand for normal goods and services. It is a general agreement from economics theories as income increase demand increase and also purchasing power of a consumer. Therefore, the expected sign of the coefficient is positive for quantity of waste generated. ii. TOTOP-This refers to total number of individuals in the household. This variable expected to have a positive correlation with quantity of waste generated per week. Because a larger household size is expected to generate higher quantity of waste even if individuals age may have difference on quantity of waste generated.

iii. GRAD-This variable refers individuals who are college graduates are work in governmental and non-governmental offices and stay outside of the house for a long time because of field work and other related activities. So the waste generation will be low. However, the generation of protective material waste may be higher in case of a fully employed family as they have less time to prepare food in the house. As such, they consume more packed consumption foods. So, this variable expected to have a negative coefficient.

iv. EXTLA-(extra land in the compound)-is a continuous variable measured in meter square that refers free space area in the compound that may use for waste decomposition and burying and it will be relate negatively with households quantity of waste generated. It is assumed that the household with extra land area may dispose some of the waste in their land, which may not be counted in the total volume of waste generated. Thus, extra land area in the house compound and the total quantity of waste will be negative.

v. SERV-This a dummy variable taking 1 if a household receives solid waste management services availability in the area and expected to generate higher quantity of waste since the quantity of waste disposed properly by city municipality collectors in case they increase demand that results waste and 0 otherwise. So, this variable is expected to have positive coefficient in the regression.

vi. AGEHH-This refers to age respondent in terms of year and it is expected to affect quantity of waste generated per week positively. Because when the age of a household increase consumption increase due to demand increases as age increase (continues variable).

The primary data for the analysis were collected from the 196 sample households in 2017. To calculate the quantity of solid waste generated, sample households were given shopping plastic bags before a day and requested for the collection of waste in these bags and the waste was weighed the next day.

Econometric results: Econometric analysis may provide better information and clearer focus on the factors that affect households quantity of solid waste generation responses such that policy recommendations can be made based on result conclusions. Before estimation was done, data exploration is an important step. To start with, to check whether multicollinearity is present or not a simple correlation coefficient matrix was conveyed. Multicollinearity is a serious problem when correlation coefficient is 0.8 and above (VIF exceeds 10) which is based on rule of thumb [35].

\begin{tabular}{|l|l|l|l|l|l|l|l|l|l|}
\hline Waste Component & Intercept & (TOTI) & AGEHH & (TOTPOP) & (EXTLA) & (GRAD) & SER & $\mathbf{R}^{-2}$ & F \\
\hline TOTW (all zones) & -2.72 & 0.25 & 0.51 & 0.50 & 0.12 & 0.14 & 0.25 & 0.25 & 22 \\
& $(7.6)$ & $(6.24)^{\star *}$ & $(1.36)$ & $(8.5)^{\star *}$ & $(1.58)$ & $(2.7)$ & $(6.24)$ & \\
\hline TOTW (inner) & -2.25 & 0.19 & 0.54 & 0.55 & -0.84 & -0.13 & 0.19 & 0.38 & 16 \\
& $(-3.8)$ & $(2.79)^{\star}$ & $(2.55)$ & $(5.8)^{\star *}$ & $(-1.9)$ & $(-0.37)^{\star *}$ & $(2.79)$ & & \\
\hline
\end{tabular}




\begin{tabular}{|c|c|c|c|c|c|c|c|c|c|}
\hline TOTW (Middle) & $\begin{array}{l}-2.9 \\
(-3.6)\end{array}$ & $\begin{array}{l}0.26 \\
(3.04)\end{array}$ & $\begin{array}{l}-0.08 \\
(2.5)\end{array}$ & $\begin{array}{l}0.59 \\
(5.5)^{\star *}\end{array}$ & $\begin{array}{l}0.04 \\
(0.47)\end{array}$ & $\begin{array}{l}-0.32 \\
(-3.72)\end{array}$ & $\begin{array}{l}0.26 \\
(3.04)\end{array}$ & 0.27 & 11 \\
\hline TOTW (Outer) & $\begin{array}{l}-3.26 \\
(-6.2)\end{array}$ & $\begin{array}{l}0.45 \\
(6.08)^{*}\end{array}$ & $\begin{array}{l}-0.75 \\
(-2.12)\end{array}$ & $\begin{array}{l}0.38 \\
(2.79)\end{array}$ & $\begin{array}{l}0.09 \\
(1.04)\end{array}$ & $\begin{array}{l}0.15 \\
(0.58)\end{array}$ & $\begin{array}{l}0.45 \\
(6.08)\end{array}$ & 0.27 & 14 \\
\hline $\begin{array}{l}\text { Figure within bra } \\
\text { Source: field sur } \\
\text { *** Significance }\end{array}$ & $\begin{array}{l}\text { ndicate't } \\
017 \\
\text { ** Sign }\end{array}$ & $n d{ }^{*}$ & $10 \%$ & & & & & & \\
\hline
\end{tabular}

Table 10: Factors affecting solid waste generation.

There is no problem of multicollinearity (VIF=2.7). The goodness of fit for the model has been tested in this analysis with some diagnostic tests which fulfill the following measures of respectable results. First, $\mathrm{R}^{2}$ value (which is a measure of goodness of fit of the estimated regression model) of 0.51 depicts a good fitting of the model, which defines that $51 \%$ of the variation in change of the waste generation of the households could be explained by the covariant in the model. The F-test shows that the estimated regression is quite meaningful in the sense that the dependent variable is related to every explanatory variables. The linear relation of the model is highly significant (the pvalue for the F-test is less than 0.001). Second, the signs of the predicted coefficients are reliable. The estimation result of waste generation and socioeconomic model has been shown in Table 10. This study has found that income and household size were expectedly positive and highly significant.

The estimation result of waste generation and socioeconomic model has been shown in Table 10. This study has found that income and household size were expectedly positive and highly significant. The positive coefficient on income variable (TOTI), at 5\% significance level, indicates that holding all other variables constant, higher income people are generating more waste than the lower income people. The positive relationship between TOTI and household quantity of waste generation is generally supported by the previous literature [36-38]. This result seems reasonable since as income increase demand for necessity goods and services increase.

The positive coefficient on households size, at 5 percent level of significance, indicates that holding all other variables constant, large family are generating more waste than the small family. A larger household size is expected to generate higher quantity of waste since more households are included in the unit; thus, the sign is also expected to be positive. The coefficient of education variable is positive but it is not significant. However, a number of other studies have also found that the effect is positive but statistically not significant $[36,38,39]$.

Extra land around the house in meter square has positive but insignificant effect is consistent with Owens [38]. In the study area, there are very few houses have open area because of urbanization growth, high population density and have high economic value of houses in the city.

\section{Economics of solid waste management}

Computing households WTP: According to Hanemann [40] one of the main objectives of estimating empirical WTP for open ended valuation questions survey responses from maximum WTP figures reported by the respondent household can be simply add and divide the sample size to gain mean WTP of sample as well as stratified zones separately.

$$
\text { Mean WTP of total sample }=\sum_{i=1}^{n} T i / 3
$$

Where: 'Ti' is the reported maximum WTP amount by surveyed households and ' $n$ ' is the sample size. The same thing for calculating means WTP, for each zone of sample households:

$$
\text { Mean WTP for each zone }=\sum_{i=1}^{n} K_{i} / 4
$$

Where: 'Ki' is the reported maximum WTP amount by core, middle and outer zones and ' $n$ ' the number of households in each sample zone.

The total amount households are willing to pay (aggregate benefits) to improve solid waste management is used as a measure of the value of the cost of poor solid waste management to the city. Thus, how much households are willing to pay is the economic cost of services improvement in the city. To arrive at this, the mean WTP from the sample is extrapolated across the population. Using the population mean permits us to extrapolate the estimates for the entire population. Therefore, the estimated aggregate WTP for Bahir Dar city is shown in Table 11. In the estimation we used the following step:

i. Calculate the mean WTP (column five) we multiply the number of households by this mean WTP to estimate TWTP;

Table 11 shows about the households' waste disposal and their willingness to pay for better service provision by the municipality. About $48.98 \%$ households participate by paying an average of 8.00 Ethiopian Birr (1\$=27.23 EB) per month for collection of their wastes with their water bill. However, the participation rate is different for different zones. About $58.57 \%$ are participating in inner zone, while in the outer and middle zones the number of households only $41.07 \%$ and $45.71 \%$ respectively. This is because of households who lives in rent houses and households who didn't have water bill didn't participate by sharing solid waste management cost. Almost $86.2 \%$ households are willing to pay for the improved SWM service supply and the mean amount of WTP is 11.3 EB per month per household without any restriction with water bill and living in rented houses. 
Citation: Tassie Wegedie K (2018) Household Behavior and Demand for Better Solid Waste Management Services: A Case of Bahir Dar City, Amhara National Regional Stat, Ethiopia. Adv Recycling Waste Manag 3: 152. doi:10.4172/2475-7675.1000152

Page 10 of 14

\begin{tabular}{|c|c|c|c|c|c|c|c|c|c|}
\hline \multirow[t]{2}{*}{$\begin{array}{l}\text { Zone } \\
\text { (1) }\end{array}$} & \multicolumn{3}{|c|}{$\begin{array}{l}\text { People actually participating the fee collection } \\
\text { system }\end{array}$} & \multicolumn{3}{|c|}{$\begin{array}{l}\text { People ready to pay and amount of } \\
\text { willingness to pay }\end{array}$} & \multicolumn{3}{|c|}{$\begin{array}{l}\text { Total WTP which includes Willingness to } \\
\text { additional pay and the monthly fee }\end{array}$} \\
\hline & $\begin{array}{l}\text { Number of } \\
\text { Sample HH (2) }\end{array}$ & $\begin{array}{l}\text { Average fee } \\
\text { in EB. (3) }\end{array}$ & $\begin{array}{l}\text { Tot. Ave } \\
\text { (4) }\end{array}$ & $\begin{array}{l}\text { Number of } \mathrm{HH} \\
\text { (5) }\end{array}$ & $\begin{array}{l}\text { Average WTP } \\
\text { in EB. (6) }\end{array}$ & $\begin{array}{l}\text { Tot Ave } \\
(7)\end{array}$ & $\begin{array}{l}\text { Number } \\
(8)\end{array}$ & $\begin{array}{l}\text { Average } \\
\text { Amount in EB. } \\
\text { (9) }\end{array}$ & $\begin{array}{l}\text { Tot. Ave } \\
\text { (10) }\end{array}$ \\
\hline All Zone & $96(48.98)$ & 8 & 3.92 & $169(86.2)$ & 13.11 & 11.3 & 265 & 21.11 & 15.22 \\
\hline inner & $41(58.57)$ & 8 & 4.69 & 69 (98.6) & 19.6 & 19.32 & 110 & 27.60 & 24.01 \\
\hline Middle & $32(45.71)$ & 8 & 3.66 & $55(78.6)$ & 12.25 & 9.625 & 87 & 20.25 & 13.29 \\
\hline Outer & $23(41.07)$ & 8 & 3.29 & $45(80.4)$ & 7.48 & 6.01 & 68 & 15.48 & 9.30 \\
\hline
\end{tabular}

Table 11: Cost of households for SWM and their willingness to pay.

The total willingness to pay is the amount of the actual fee and the amount of willingness to pay since the question was about the willingness to pay over and above the existing fee for the better management of the waste. About $86.2 \%$ of the sample households are willing to pay for the management of the waste and the average amount is $13.11 \mathrm{~EB}$ while the amount is $\mathrm{EB} 19.60$ in the inner, EB 12.25 and EB 7.48 in the in the middle and outer zones respectively.

WTP for better SWM services is different across different zones. Total number of households (Col. (1)) is obtained by taking the proportion of sample households falling who participating the fee collection system and multiplying it by the total number of households (220344). To get the total number of households who are currently paying $8 \mathrm{~EB}$ per month, we multiply average fee $(\mathrm{Col}(2))$ by the total sample households (196) and divide gives total average (col (3)). The grand total willingness to pay is obtained by multiplying total average WTP (10) by total households in the city to calculate the TWTP $\left(15.22^{\star} 54,000=821,888 \mathrm{~EB}\right.$ per month which is the revenue for city municipality) and this is the amount all households in Bahir Dar city are expected to pay per month if the proposed plan of improved solid waste management is to be applied.

Logit model specification: The choice of econometric model depends on the nature of the dependent variable i.e., nominal, ordinal, interval and/ratio scale. Households' WTP was the dependent variable of this study which takes 1 if the household is WTP 0 , otherwise. Therefore, linear probability, binary logit and probit model are used to express and estimate the mathematical relationships between explanatory variables and the binary dependent variable which has qualitative responses. In linear probability model, the estimated probability of the dependent variable lies out of the interval $0<\mathrm{p}<1$ unlike logit and probit model. How do logit models differ from probit models? This question is answered by Park. The core difference lies in the distribution of the error term. In the logit model, error term is assumed to follow the standard logistic distribution; whereas, probit model is assumed to follow the standard normal distribution. With this minor difference, binary logit is preferable as compared to binary probit because of its mathematical simplicity and interpretation. Following this, binary logit model was employed for this study.

Household heads WTP for better SWM services will depend upon a number of determinate factors. "Willingness to pay" was regressed as a function of independent variables used for this study such as household aggregate income per month (TOTI), time required to reach waste collection container (TTR), the total quantity of the waste generated within a week (TOTW), extra land area in the compound (EXTLA), and college graduate people (GRAD) (was taken as dummy variable; 1 if there is college graduate and 0 otherwise); Consciousness Training (COTR) was taken as a dummy variable ( 1 if households gain training and 0 otherwise). A collected data analysis was made with the help of the STATA version 13 software. logit model involving the estimation of the probability of willingness to pay for improved waste management services (WTP) as a function of independent variables () will be used for this study as specified by Yusuf [41-43], and that of Naeem [44]. The logit model specified as:

$$
\begin{aligned}
& W T P^{*}=\alpha+X \beta+\mu i=\alpha+Z+\mu i \\
& \operatorname{Pr}(W T P i=1)=F(\alpha+Z) ; \\
& \operatorname{Pr}(W T P i=0)=1-F(\alpha+Z)
\end{aligned}
$$

Where: $\mathrm{WTP}=1$ for a household head who is WTP and $\mathrm{WTP}=0$ for otherwise. $\beta=\mathrm{A}$ Vector of coefficients' and $\mathrm{X}=$ vectors explanatory variables; $\alpha=$ constant coefficient; $\mu \mathrm{i}=$ Error term.

The logit model uses a logistic cumulative distributive function to estimate probability as follows: So, the probability of the event occurring is a logistic function of the independent variables.

$$
\begin{aligned}
& \operatorname{Pr}(Y=1)=E(Y=1 / X i)=\frac{1}{1+e^{-(Z)}}=\frac{1}{1+e^{-\left(\beta_{0}+\beta X\right)}} \\
& \operatorname{Pr}(Y=1 / X)+\operatorname{Prob}(Y=0 / X)=1 \\
& \text { So, } \operatorname{Pr}(Y=0 / X)=1-\operatorname{Prob}(Y=1 / X)
\end{aligned}
$$

Since the logit model is not linear, the coefficients are not necessarily a measure of change of probability for a unit change in covariant. Logit model is related to the odds for a binary outcome. That means the probability of the outcome is measured by the odds of occurrence of an event. Usually, the logit model is written as log-odds ratio. The odds-ratio is thus given by:

$$
L=\frac{\operatorname{Pr}(Y=1 / X)}{\operatorname{Pr}(Y=0 / X)}=\frac{\operatorname{Pr}(Y=1 / X)}{1-\operatorname{Pr}(Y=1 / X)}
$$

So, that the log-odds ratio finally becomes:

$\ln L=\mathbf{L}=\ln \left(e^{Z}\right)=T W T P$

Final logit model specification is: 
$\mathrm{WTP}=\beta_{0}+\beta_{1}$ TOTW $+\beta_{2}$ GRAD $+\beta_{3} \quad$ EXTLA $+\beta_{4} \quad \mathrm{COTR}+\beta_{5} \quad$ TTR $+\beta_{6}$ TOTI $+\mathrm{e}$

Explanatory variables definition with their expected hypothesized relation with households WTP:

1. TOTI (total income household)-this variable refers the monthly aggregate income of the household in terms of Ethiopian Birr (EB) and will includes the income of all other members of household from all sources and It is a continues variable and expected affect positively the Willingness to Pay (TWTP) i.e., higher the income higher will be WTP for better solid waste management services.

2. TTR(total time required for waste disposal container)-refers time requirement to dispose wastes generated in the house in the solid waste collection container and it is a continuous variable and will affect WTP positively to i.e., more the time needed for the disposal of waste at the free collection center, higher the WTP for better solid waste collection system.

3. COTR (consciousness training)-this is a dummy variable taking the value 1 if a household gain a consciousness training related to solid waste management methods and related issues and 0 otherwise and will also affect positively households WTP i.e., as people are more conscious regarding the bad effects of improper disposal of waste they are ready to pay for improved waste management services.

4. EXTLA (extra land in the compound)-is a continuous variable measured in meter square that refers free space area in the compound that may use for waste decomposition and burying and it will be relate negatively with households WTP, i.e., higher the land area around the house, lower will be the Willingness to Pay for waste disposal since people may use their waste as a soil conditioner in the kitchen garden and as source of income.

5. GRAD (college graduate)-this variable is taken to capture the level of understanding of the respondent about the desirability of proper solid waste management. Households whose heads and or other members have higher education may value improved environment more. Such households expected to pay for better waste management services than others. So, it also affect households Willingness to pay positively, i.e., educated people will be cautious about the negative effects of disorganized municipal solid waste disposal.

6. The total quantity of the waste generated (TOTW)-this variable stands for the quantity of solid waste the household generates within a week. For this the unit of measurement used is a shopping plastic bag which is common almost for all respondents during survey. The study hypothesized WTP to be positively related with the TOTW.

The determinants of households WTP regression results are shown in Table 12. As expected household total income has a positive effect on WTP at $1 \%$ significance level. The coefficient of income is positive $(0.81)$, if all other variables are kept constant it shows that as total income of a households increase by one EB, WTP increase by $0.81 \mathrm{~EB}$. More meaningful explanation of odds ratio, if total income a household increase they are 1.001 times likely WTP. This result confirms the findings of Yusuf [41-43] and that of Naeem [44] showed a positive association between total income and households WTP.

The time requirement to dispose solid waste into the collection container has also a positive and significant relationship with the households WTP at $1 \%$ significance level. It has a positive effect on households WTP as expected. The coefficient value of 0.11 shows, if all other are kept constant as a time requirement for waste disposal into public waste collection container increase by one unit, households WTP increase by 0.11 units. Odds ration shows if households time requirement for disposing waste increases they are more than 6.249 times WTP for better solid waste management services.

\begin{tabular}{|c|c|c|c|c|c|c|c|c|c|c|}
\hline \multirow[t]{2}{*}{ No equation } & \multirow[t]{2}{*}{ Dep. Variable } & \multicolumn{7}{|c|}{ Independent Variables } & \multirow[t]{2}{*}{ AjuR $^{2}$} & \multirow[t]{2}{*}{$F$} \\
\hline & & Const & тотІ & GRAD & TTR & EXTL & COTR & TотW & & \\
\hline \multirow[t]{3}{*}{1} & TWTP & 1.86 & 0.81 & 0.03 & 0.11 & 0.01 & -0.17 & 0.25 & 0.31 & 8 \\
\hline & Odd Ratio & $5.7 \mathrm{e}^{-10}$ & 1.001 & 2.93 & 6.249 & .0184 & .01282 & 1.158 & - & - \\
\hline & 't' value & - & $4.15^{\star}$ & $0.49^{*}$ & $2.26^{*}$ & 0.38 & $-2.35^{\star *}$ & 0.78 & - & - \\
\hline \multirow[t]{2}{*}{2} & TWTP & 1.59 & 0.28 & 0.02 & 0.07 & -0.001 & - & - & 0.27 & 8 \\
\hline & 't' value & - & $4.75^{\star}$ & 0.256 & $1.96^{\star *}$ & -.036 & - & - & - & - \\
\hline \multirow[t]{2}{*}{3} & TWTP & 1.62 & 0.35 & - & 0.06 & 0.05 & - & -0.11 & 0.14 & 7 \\
\hline & 't' value & - & $5.31^{*}$ & - & 1.31 & 1.33 & - & $-1.91^{* *}$ & - & - \\
\hline \multirow[t]{2}{*}{4} & TWTP & 1.45 & 0.25 & 0.39 & 0.11 & -0.04 & - & - & 0.35 & 4 \\
\hline & 't' value & - & $2.44^{*}$ & 1.32 & $2.16^{\star \star}$ & -0.96 & - & - & - & - \\
\hline
\end{tabular}

Table 12: Willingness to Pay and its Relationship with explanatory Variables.

College graduate (GRAD)-this variable is significant at $1 \%$ significance level and has a positive effect on WTP as was expected.
The variable has coefficient of 0.03 , which shows that if the number of college graduate in the household increases by one percent, on average 
households WTP for better solid waste management services increased by 0.03 percent. In terms of odds ratio if households number of college graduate increases, they are 2.93 times WTP if such services offered. This result shows that education is an important determinant factor of willingness to pay. In terms of odds interpretation antilog of the coefficients is 2.93 , and this result suggests that as the respondent's level of education increases by a year of education their probability of willingness to pay also increases by 2.93 times. AS evident from Aklilu [34,45]. Ajewole also suggest a positive relationship between education level of the respondents and WTP for better waste management services [46]. Education has spillover effect, because of this we use household level of education and or other member (s) level of education for this study.

EXTL-this variable was expected to have a negative effect, i.e., households who have open spaces around the houses are less likely to pay than those who haven't space for waste decomposition for agricultural productivity or soil conditioner. But the result shows households having extra land areas have positive but insignificant effects on their WTP ability for better service provision by city municipality. Therefore open space around the house is not determinate factor for households WTP for improved SWM services in Bahir Dar city.

Similarly, COTR was expected to have a positive effect, i.e., households who gain consciousness training related to SWM are more likely WTP than other who are not get training. But the sign is negative and is significant $(\mathrm{P}<0.005)$. It may be because of the low quality of the training. In the survey it was considered that those who have attended any program, which simply discussed about the waste management or environmental issues, were considered as consciousness training. The coefficient -0.17 indicates as other variables kept constant, if the number of households getting training increases by $1 \%$, their WTP decreases by $00.17 \%$. In terms of odds ratio, if a household who gains training 0.17 times less likely to pay for improved SWM services supply.
TOTW-this variable was expected to have a positive effect, i.e., households who generates more solid waste per week are more WTP than those who are not. But even if it has positive effect it is insignificant which may enable to conclude that quantity of waste generated is not an important variable in explaining whether households WTP or not for improved SWM services. This result opposes the findings of some authors $[45,47]$ that households quantity of waste generation per week is an important determinant factor that households WTP or not to cooperate for improved solid waste management services.

If one variable is throw down i.e., variable COTR, the regression analysis result shown in Equation 1, Table 13. The total household income and time required public waste collection container are significant and open land area around the house and college graduate has an insignificant effect on households WTP for improved solid waste management services.

An attempt was made to see the relationship of total waste and total willingness to pay. If we look at the regression result after adding total waste (TOTW) as an independent variable, it shows a negative relation with Willingness to Pay. This shows that the volume and quantity of waste have a very low effect on the Willingness to Pay. It seems to be true in this context since the ability to pay is very important for the Willingness to Pay. The rich people may be generating low volume of waste and the poor may be generating high volume of waste since waste volume/quantity is highly related with the size of the population (Equation 2, Table 13).

Reasons of unwillingness to pay for better SWM services: Those households who were unwilling to pay, were asked to state the reason of their unwillingness to pay reason. Households have given more than one reason for unwilling to pay for the better waste management services supply. The table shows that from the sample households' data collected 27 households who were unwilling to pay for proposed better service supply by city municipality.

\begin{tabular}{|c|c|c|c|c|}
\hline Causes & Total No of HH & Inner & Middle & Outer \\
\hline It is the duty of the Municipality & $1(4)$ & 1(1.11) & 0 & 0 \\
\hline It is the duty of the government & 0 & 0 & 0 & 0 \\
\hline Income is very low and could not afford & $3(11)$ & $2(22)$ & $1(12.5)$ & 0 \\
\hline My house's waste had not made any problem to me & $6(22)$ & $3(33.33)$ & $1(12.5)$ & $2(20)$ \\
\hline $\begin{array}{l}\text { Waste collection is continuing in one or other way and no other } \\
\text { problem }\end{array}$ & $14(52)$ & $3(33.33)$ & $5(62.5)$ & $6(60)$ \\
\hline Volume and quantity is very low & $1(4)$ & 0 & 0 & $1(10)$ \\
\hline Majority of waste is reusable and applicable to own self & $2(7)$ & 0 & $1(12.5)$ & $1(10)$ \\
\hline Total & $27(100)$ & $9(100)$ & $8(100)$ & $10(100)$ \\
\hline
\end{tabular}

Table 13: Reasons of unwillingness to pay.

The above table shows that households 27(52\%) were not willing to pay as their waste was collected and they do not have any problems from the waste. From this households, Some 6(22\%) of them do not feel the problem from the waste since they have sufficient space to throw the waste either within their compound or outside. Few households were not ready to pay, as their income was very low due to opportunity cost and cannot affordable to pay. They account for only $3(11 \%)$ among the unwilling households. They feel that their priority is hand to mouth survival and not the waste related matters. No households feel that it is the duty of the municipality and the 
government and, so they are not willing to pay. Only $1(4 \%)$ of sample households viewed they did consider the volume and quantity of waste generated is low and does not incur cost of SWM service provision. Across zones unwillingness to pay is higher in outer and then inner zones as compared with middle zone. Two households (7\%) states that they are not volunteer to participate cost share for waste management activities because of majority of waste is reusable and applicable to own self. In all zones the main reason behind unwillingness to pay was waste collection has been continuing in one or other way and no other problem relating to waste inadequate disposal and they believes the general taxes should cover cost of collection, transportation and disposal of solid waste.

\section{Conclusion and Recommendation}

In conclusion, solid waste management has become an increasing environmental and public health problems everywhere in the world in general, in developing countries including Ethiopia in particular. Inadequate supply of SWM services has been a main environmental problem in Bahir Dar city. Solid waste collection coverage is very low (52\%). This implies solid waste is through everywhere in the city such as open spaces, green areas, rivers, canal ditches and due to this waste is spread to all residential houses in the form of dust by high wind and causes disease. These increases the cost of street sweeping in the main roads of the city and also the river of Nile is carrying various wastes in the country side with its own implications on the health of animals uses the river water for various activities. The major cause of this problem is inadequate finance for these service provision by the municipality. Hence the assessing households behavior on solid waste generation and management as a complementary with examine determinates of households WTP for better SWM services supply is possibility of cost recovery. From the interviewed households $169(86.2 \%)$ willing to participate by sharing cost of solid waste management activities. From the interviewed households per capita waste generation was $0.22 \mathrm{~kg} /$ person/day which is lowest in the outer zone and highest in the inner zone as it compared with middle zones. Primary collection of waste is done by residents within their home premises and for this they used various types of bins like buckets, empty oil drums, paper cartons plastic bags and others. From sample households, 151(77\%) households didn't practice solid waste separation because of different reasons in the study area it was also found that separation practices are the highest in the outer zone relative to other zones.

The result shows only 53(47.3\%) households received solid waste management services weekly. While $18(16 \%)$ households, $29(25.9 \%)$ households, 12(10.7\%) households received solid waste management services within 15 days, 21 days and once in a month, respectively, and $84(43 \%)$ residents never received solid waste collection, transportation and final disposal in to landfill services until this interview was made. These Ethiopia has environmental policy. The policy address different environmental issues including SWM. "States government and citizens shall have the duty to protect the environment". But because of implementation of laws and proclamations at the root level illegal waste disposal is common all zones even if there is difference due government service supply discrimination (focus on center areas and tourist destination centers). Thus, inflexible regulations with environmental awareness programs for household organizing and composting can reduce the volume and quantity of waste for land filling. The waste component relationship shows that size of the household and income are the major factor determining the total quantity of the waste. It was also found that total income is a main determinate factor of households WTP. Based on our research findings, the following points are recommended:

- As pointed out several times in the discussion above the present solid waste management system in Bahir Dar city is less than adequate. Organizational strengthening, better management of the conservancy section would certainly help to change this gloomy condition of solid waste management and bring it to acceptable standards. Manpower, number of vehicles, tricycles and rickshaw vans could be increased.

- Adequate supervision and management is imperative to ensure that wastes are collected properly and on time every day.

- Public awareness campaigns could be initiated by the government so that people and community are better aware of the health and environmental hazards that improper solid waste management poses. Not only in media and newspapers solid waste management issues could be introduced in textbooks so that children grow up learning about it and as responsible citizens they themselves look for ways to solve the problem. Community involvement is the key towards solving this burning issue.

- There is no any type Biogas plants used by many factories in and around Bahir Dar city to generate electricity from solid wastes. Government could make it mandatory for factories/poultries/ farms generating a certain amount of solid waste to have biogas plants. Certain tax incentives could also be given to those complying with these new regulations.

- The study also revealed a strong positive relationship between household family size and quantity of waste generated. It is recommended that measures be embarked upon to encourage people especially the younger generation who are yet to have children of their own to have smaller family sizes rather than larger ones.

- Service charges for solid waste management should be based on willingness and ability to pay than making it flat and compulsory across all income groups. This means service charges should be set at a level that does not encourage illegal dumping and maximize cost recovery. Therefore, this study recommends that the proposed sanitation fees need to be revised before they are put into operation based on willingness and ability to pay.

- Household aggregate income has a strong positive relationship with households WTP. As such to increase households' preparedness to participate for better solid waste management services, measures should be undertaken in order to diversifying the incomes of households. Such measures may include increasing the national daily minimum wage so that incomes will go up significantly. Measures should also be undertaken to provide jobs for the unemployed. This way, the income of previously unemployed persons who now have jobs will add to their households' incomes to enhance their households' willingness to pay.

\section{Competing Interests}

The author declared that there are no potential competing interests with respect to the research, authorship, and/or publication of this paper. 
Citation: Tassie Wegedie K (2018) Household Behavior and Demand for Better Solid Waste Management Services: A Case of Bahir Dar City, Amhara National Regional Stat, Ethiopia. Adv Recycling Waste Manag 3: 152. doi:10.4172/2475-7675.1000152

Page 14 of 14

\section{References}

1. Demanya BK (2006) The role of local knowledge in planning and managing urban solid waste: The tale of two (2) West African Cities, Accra and Kumasi, Ghana.

2. Dimitre G (2011) The Changing Dynamics of Urbanization in Developing Countries.

3. Abdullah B (2009) Global Urbanization: Trends, Patterns, Determinants and Impacts.

4. Alam PA (2013) Impact of solid waste on health and the environment IJSDGE 2: 165-168.

5. Solomon C (2011) Assessment of municipal solid waste management service in Dessie Town.

6. Pradhan UM (2009) Sustainable solid waste management in a mountain ecosystem: Darjeeling, West Bengal, India.

7. Zerbock O (2003) Urban solid waste management, waste reduction in developing countries. School of Forest Resource and Environmental Science, Michigan Technological University, USA.

8. Medina M (2002) Globalization, development, and municipal solid waste management in third world cities. Institute of Advance Studies, Mexico, pp: 1-23.

9. Modak P (2010) Municipal solid waste management: Turning waste into resources. Shanghai Manual-A Guide for Sustainable Urban Development in the 21st Century.

10. Zurbrügg C, Drescher S, Patel A, Sharatchandra HC (2004) Decentralised composting of urban waste-an overview of community and private initiatives in Indian cities. Waste Manag 24: 655-662.

11. Alam P, Ahmade K (2013) Impact of solid waste on health and the environment. Intern J Sustain Develop Green Eco 2: 165-168.

12. Monyoncho G (2013) Solid Waste Management in Urban Areas Kenya: A case study of Lamu town.

13. Ejaz N (2010) Environmental impacts of improper solid waste management in developing countries: A case study of Rawalpindi city. The Sustain World, pp: 379-388.

14. Chinasho A (2015) Review on community based municipal solid waste management and its implication for climate change mitigation. American J Scien Industr Res 6: 41-46.

15. Kassa M (2010) The Challenges of Solid Waste Management in Urban Areas, the Case of Debremarkos Town. Addis Ababa University, Ethiopia.

16. UNEP (2010) Assessment of the Solid Waste Management System in Bahir Dar Town and the Gaps identified for the Development of an ISWM Plan. Forum for Environment.

17. Christian RL (2014) Financial sustainability in municipal solid waste management-costs and revenues in Bahir Dar, Ethiopia. Waste Manag 34: 542-552.

18. Ayana Y (2007) Plastic bag waste generation rate in Bahir Dar city, Ethiopia.

19. Mekete D (2009) Solid Waste Management in Bahir Dar City. School of Civil and Water Resources Engineering, Bahir Dar University.

20. Fikreyesus D (2011) Ethiopia Solid Waste \& Landfill. Country Profile and Action Plan: Community Development Research.

21. Getahun B (2011) Waste generation in Ethiopian municipalities.

22. CSA (2007) (Central Statistical Authority of Ethiopia) Summary and statistical report of the population and housing censes result of Ethiopia.

23. Mekonnen FH (2012) Liquid waste management: The case of Bahir Dar, Ethiopia. Ethiop J Heal Develop 26: 49-53.

24. Edmealem B (2013) Assessment of the sustainability of solid waste collection and transport services by MSEs, in the case of Bahir Dar city, Ethiopia.
25. FFE (2010) Forum for Environment Assessment of solid waste management system of Bahir Dar city, for the development of an ISWM Plan.

26. UNEP (2010) Solid waste characterization and quantification of Bahir Dar City for the development of an integrated solid waste management Plan.

27. Birtukan B (2013) Household Demand for Improved Solid Waste Management Service in Ethiopia: The Case of Bahir Dar City.

28. Report (2016) Annual report of Bahir Dar city municipality, Department of solid waste management.

29. UNEP (2010) Assessment of the solid waste management system in Bahir Dar Town and the Gaps identified for the Development of an ISWM Plan.

30. Dream IP (2010) Dream light plc Solid waste characterization and quantification of Bahir Dar city.

31. Cochran WG (1977) Sampling techniques (3rd edn.), Wiley series in productivity and applied mathematical statistics. New York, USA.

32. EPE (1998) Environmental Policy of Ethiopia.

33. Richardson RA, Havlicek J (1978) Economic Analysis of the Composition of Household Solid Wastes. J Environ Econom Manag 5: 103-111.

34. Gujarati DN, Porter DC (1999) Essentials of Econometrics.

35. Vining J, Ebreo A (1992) Predicting recycling behavior from global and specific environmental attitudes and changes in recycling opportunities. J App Soc Psychol 22: 1580-1607.

36. Mohai P (1985) Public concern and elite involvement in environmental conservation issues. Soc Sci 66: 820-838.

37. Owens J, Dickerson S, Macintosh DL (2000) Demographic covariates of residential recycling efficiency. Environ Behav 32: 637-650.

38. Afroz R, Hanaki K, Kurisu KH (2008) Factors Affecting Waste Generation and Willingness to Recycle: A Study in a Waste Management Program in Dhaka city, Bangladesh.

39. Hanemann WM, Loomis J, Kanninen B (1991) Statistical efficiency of double-bounded dichotomous choice contingent valuation. American J Agricul Econom 73: 1255-1263.

40. Yusuf SA, Ojo OT, Salimonu KK (2007) Household willingness to pay for improved household solid waste management in Ibadan-North LGA of Oyo State, Nigeria. J Environ Exten Univer Ibadan 6: 57-63.

41. Ezebilo EE (2011) Willingness to pay for improved residential waste management in a developing country. Intern J Environ Sci Technol 10: 413-422.

42. Anjum R (2013) Willingness to pay for solid waste management Services: A case study of Islamabad, Pakistan. Pakistan Institute of Development Economics.

43. Khattak NU, Khan J, Ahmad I (2009) An analysis of willingness to pay for better solid waste management services in urban areas of district Peshawar, Pakistan. Agric 25: 3.

44. Aklilu A (2002) Households' willingness to pay for improved solid waste management in the case of Addis Ababa, Ethiopia.

45. Ajewole A (2012) Gender and urban environment, analysis of willingness to pay for waste management disposal in Ekiti State, Nigeria. American J Contem Res 2: 228-234.

46. Kweetey S (2014) Household demand and willingness to pay for solid waste management service in Tuobodom in the Techiman-North District, Ghana.

47. Murad MW, Raquib MA (2007) Willingness of the poor to pay for improved access to solid waste collection and disposal services. J Environ Develop 16: 84-101. 